\title{
Neonatal Dacryocystitis
}

National Cancer Institute

\section{Source}

National Cancer Institute. Neonatal Dacryocystitis. NCI Thesaurus. Code C116819.

Inflammation of the lacrimal sac in a newborn due to blocked drainage of tears or infection. 